\title{
Adaptation to a marginal intake of energy in young children
}

\author{
BY N. KENNEDY', A. V. BADALOO ${ }^{1}$ AND A. A. JACKSON ${ }^{1,2, *}$ \\ ${ }^{1}$ Tropical Metabolism Research Unit, University of the West Indies, Mona, Kingston 7, Jamaica \\ and ${ }^{2}$ Department of Human Nutrition, University of Southampton, Bassett Crescent East, \\ Southampton SO9 $3 T U$
}

(Received 20 February 1989 - Accepted 22 September 1989)

\begin{abstract}
Six male children, aged 8-28 months, were studied for three consecutive periods of 1 week each. They were given diets that provided $1.7 \mathrm{~g}$ protein $/ \mathrm{kg}$ per $\mathrm{d}$ and supplements of minerals and vitamins, with a metabolizable energy intake during the 1st, 2nd and 3rd week of 419, 293 and $335 \mathrm{~kJ}(100,70$ and 80 kcal)/kg per d, diets 1, 2 and 3 respectively. All the food offered was consumed. Each child was weighed at the same time each day on an electronic balance. On the 6th and 7th day of each study period urine and stool were collected for $24 \mathrm{~h}$ to assess nitrogen balance. Using linear regression analysis it was shown that all children gained weight on diet $1,2 \cdot 3$ (SD 1.3) $\mathrm{g} / \mathrm{kg}$ per $\mathrm{d}$, and five of six children gained weight on diet 3 , the mean for the whole group being 2.7 (SD 2.3 ) $\mathrm{g} / \mathrm{kg}$ per $\mathrm{d}$, not significantly different. On diet 2 all children lost weight, -5.4 (SD 1.3) $\mathrm{g} / \mathrm{kg}$ per $\mathrm{d}$, highly significantly different from each of the other dietary periods. Using asymptotic regression analysis it could be shown that the rate of weight loss during the first part of the week on diet $2,-11 \mathrm{~g} / \mathrm{kg}$ per d, was greater than at the end of the week, $-2 \mathrm{~g} / \mathrm{kg}$ per d, with a tendency towards a steady weight by day 7 . Apparent $\mathbf{N}$ retention $(\mathrm{mg} / \mathrm{kg}$ per $\mathrm{d}$ ) was positive at the end of each of the three dietary periods: diet 1, 112 (SD 25); diet 2, 54 (SD 34); diet 3, 82 (SD 20). In five of the six children there was a marked reduction in stool frequency on diet 2 compared with diet 1 , that was maintained to the period on diet 3 . The findings suggest that during the period on diet 2 there was a saving of energy of the order of $105 \mathrm{~kJ}(25 \mathrm{kcal}) / \mathrm{kg}$ per $\mathrm{d}$, which lasted through into the period on diet 3 .
\end{abstract}

Energy expenditure: Energy intake: Children

The energy requirement of an individual during childhood has been defined as the level of energy intake needed to maintain health, growth and physical activity (Food and Agriculture Organization/World Health Organization/United Nations University (FAO/WHO/UNU) Expert Consultation, 1985). In practice the requirements of infants and children have been derived from the energy intakes of healthy children growing normally (Whitehead et al. 1981; FAO/WHO/UNU Expert Consultation, 1985). A problem with this method is that it ignores the effect that metabolic or behavioural adaptations have on energy requirement (Waterlow, 1988). It has also been noted that an energy intake adequate for maintaining body-weight in malnourished children, $398 \mathrm{~kJ} / \mathrm{kg}$ per d, was insufficient after recovery, suggesting that adaptation to a chronically inadequate diet had occurred in the malnourished child (Golden et al. $1977 \mathrm{~b}$ ). This hypothesis of an adaptation in energy metabolism in the malnourished state is substantiated by the fact that total energy utilization has been found to be significantly less in malnourished than in recovered children ( 277 v. $323 \mathrm{~kJ} / \mathrm{kg}$ per d; Kerr et al. 1978) and in undernourished compared with well-nourished adults (Shetty, 1984). There may also be important racial differences in both basal expenditure and the energy expenditure for activity (Geissler \& Aldouri, 1985; Henry \& Rees, 1988).

* Requests for reprints: Professor A. A. Jackson, Department of Human Nutrition, University of Southampton, Bassett Crescent East, Southampton SO9 3TU. 
It is not clear how these savings in energy expenditure are brought about. One mechanism that could contribute to a saving in energy might be a change in protein metabolism (Waterlow, 1984). Golden et al. (1977a) have shown that malnourished children have significantly lower rates of protein turnover than recovered children. Estimates of the biochemical cost of protein synthesis are in the range of 10-15\% of basal energy expenditure (Reeds et al. 1985); with the physiological cost of protein turnover likely to be in the range of 20-35\% (Waterlow, 1988; Badaloo et al. 1989). Thus a decrease in protein turnover could make an important contribution to a saving in energy expenditure. As the accretion of body protein is determined by the relative rates of protein synthesis and degradation, a fall in protein turnover would not necessarily have to be associated with an overall decrease in the child's rate of growth. A decrease in physical activity may also account for a saving of energy in response to an inadequate dietary intake. Studies in Guatemala have suggested that such behavioural adaptation may reduce energy requirements by about $10 \%$ (Torun \& Viteri, 1981).

In the present study we have looked at weight gain, nitrogen balance and protein turnover in six male children who were given three different diets in which energy content was varied around the region of maintenance requirement (metabolizable energy intakes of 419,293 , and $335 \mathrm{~kJ}(100,70$ and $80 \mathrm{kcal}) / \mathrm{kg}$ per d, but with a constant and adequate intake of protein $(1.7 \mathrm{~g} / \mathrm{kg}$ per $\mathrm{d})$. The study follows from a previous study in which the response to $293 \mathrm{~kJ} / \mathrm{kg}$ per d was not examined (Jackson et al. 1983). We were unable to identify any changes in protein turnover, but there were unexpected changes in weight and $\mathrm{N}$ balance which are reported in the present paper.

\section{MATERIALS AND METHODS}

\section{Subjects}

Six male Jamaican children, aged 8-28 months, were studied. The children had recently recovered from severe malnutrition in the metabolic ward of the Tropical Metabolism Research Unit, and all had reached at least $90 \%$ of their expected weight for height (Hamill et al. 1979). None of the children was suffering from infection or diarrhoea at the time of study. The clinical characteristics of the subjects are given in Table 1. The study had received the approval of the Ethical Committee of the University Hospital of the West Indies, and consent was given by the parent or guardian of each child.

\section{Dietary regimens and growth rate}

Three diets were formulated from a mixture of a proprietary infant formula based on cow's milk (Pelargon, Nestlé), granulated sugar and arachis oil to provide a metabolizable energy intake of 419,293 and $335 \mathrm{~kJ}(100,70$ and $80 \mathrm{kcal}) / \mathrm{kg}$ per d (diet 1, 2 and 3 respectively), with a gross energy intake of 453,318 and $365 \mathrm{~kJ}(108,76$ and $87 \mathrm{kcal}) / \mathrm{kg}$ per d. The raw ingredients were made up by weight in an homogenizer, supplements of minerals and vitamins were added (Table 2) and the final dilution was made up by weight with water. The energy and $\mathrm{N}$ contents of the raw ingredients were determined by bomb calorimetry and Kjeldahl digestion (Jackson et al. 1983). The metabolizable energy was taken to be that defined by the manufacturer of the milk formula, with the sucrose and oil being presumed to have an energy value of 17.5 and $37.5 \mathrm{~kJ} / \mathrm{g}$ respectively. Each child was studied for three consecutive periods of 1 week and received diet 1 during the first week, diet 2 during the second and diet 3 during the third week. The diet was apportioned by weight, $100 \mathrm{~g} / \mathrm{kg}$ per d. Hence, the metabolizable energy intake was 419,293 and $335 \mathrm{~kJ} / \mathrm{kg}$ per d during the first, second and third weeks respectively. The protein intake was constant in quality and amount for the entire study period $(1.7 \mathrm{~g} / \mathrm{kg}$ per $\mathrm{d})$. All intakes were calculated on the basis 
Table 1. The clinical diagnosis* at admission and anthropometric characteristics of the children at the start of the study

\begin{tabular}{cccccl}
\hline Child no. Age (months) & Wt (kg) & Ht (mm) & Wt/ht $\uparrow$ (\%) & Admission diagnosis \\
\hline 1 & 8 & 4.085 & 540 & 97 & Marasmus-kwashiorkor \\
2 & 12 & 8.080 & 710 & 92 & Kwashiorkor \\
3 & 16 & 7.885 & 700 & 94 & Marasmus-kwashiorkor \\
4 & 28 & 10.009 & 770 & 96 & Marasmus \\
5 & 26 & 9.040 & 710 & 103 & Marasmus \\
6 & 9 & 6.552 & 640 & 99 & Marasmus-kwashiorkor \\
\hline
\end{tabular}

* Diagnosis is based on the Wellcome classification.

$\dagger$ Weight-for-height is based on the National Center for Health Statistics standards (Hamill et al. 1979).

Table 2. The composition of the three experimental diets $(\mathrm{g} / \mathrm{kg})$ formulated to provide a metabolizable energy intake of 4190,2930 and $3350 \mathrm{~kJ} / \mathrm{kg}$

\begin{tabular}{lrrr}
\hline \multicolumn{1}{c}{ Diet no.... } & 1 & 2 & 3 \\
\hline & 100 & 100 & 100 \\
Pelargon powder (Nestlé) & 82 & 4 & 30 \\
Granulated sugar & 30 & 30 & 30 \\
Arachis oil & 4525 & 3184 & 3645 \\
Gross energy (kJ/kg) & 17.2 & $17 \cdot 2$ & 17.2 \\
\hline
\end{tabular}

Daily supplements of minerals and vitamins were added to provide $(/ \mathrm{kg}$ diet): vitamin A $600 \mu \mathrm{g}$, thiamin $1.8 \mu \mathrm{mol}$, nicotinamide $54 \mu \mathrm{mol}$, ascorbic acid $227 \mu \mathrm{mol}$, vitamin D $10 \mu \mathrm{g}$, folate $11 \mu \mathrm{mol}$, potassium chloride $2 \mathrm{mmol}$, magnesium chloride $1 \mathrm{mmol}$, ferrous sulphate $18 \mu \mathrm{mol}$, zinc acetate $8 \mu \mathrm{mol}$, copper chloride $0.6 \mu \mathrm{mol}$.

of the child's weight at the point of entry to the study. Feeds were offered every $4 \mathrm{~h}$, day and night, and the amount taken at each feed was accurately recorded using an electronic balance. Body-weight was measured by an experienced observer, at the same time each day, on an electronic balance accurate to $1 \mathrm{~g}$. Height was measured weekly. All the children completed the study schedule.

\section{$N$ balance}

During the sixth and seventh day of each dietary period urine and stool were collected to assess $\mathrm{N}$ balance. Stool and urine were collected as described by Golden et al. (1981), a modification of the method of Liu \& Anderson (1967). Briefly, urine was collected by continuous aspiration from a perineal urine bag. The volume of each specimen was measured before being stored frozen in sealed vessels containing $0.5 \mathrm{ml} 6 \mathrm{M}$-hydrochloric acid. Stools were collected into preweighed polyethylene bags attached to the perianal region. Each stool was weighed and immediately frozen. The times at which urine and stool were passed were recorded, as were any losses that occurred. A record was made of stool frequency throughout each study week.

\section{Analysis}

Representative $24 \mathrm{~h}$ stool and urine specimens were made by pooling and homogenizing appropriate samples. The total $\mathrm{N}$ content of these specimens was then determined using the micro-Kjeldahl technique. All measurements were performed in triplicate against appropriate standards.

Comparisons between different dietary groups were carried out using Wilcoxon Rank sum test, linear regression analysis or asymptotic regression analysis. 
Table 3. The recorded, daily dietary intakes of the six Jamaican children during each period of 1 week on one of the three diets, compared with the planned intake of each diet

(Mean values and standard deviations)

\begin{tabular}{|c|c|c|c|c|c|c|c|}
\hline \multirow[b]{2}{*}{ Diet no.* } & \multirow[b]{2}{*}{ Week no. } & \multicolumn{2}{|c|}{$\begin{array}{l}\text { Feed taken } \\
\text { daily }(\mathrm{g})\end{array}$} & \multicolumn{2}{|c|}{$\begin{array}{c}\text { Gross energy } \\
\text { intake (kJ/kg } \\
\text { per d) }\end{array}$} & \multicolumn{2}{|c|}{$\begin{array}{l}\text { Protein intake } \\
(\mathrm{g} / \mathrm{kg} \text { per } \mathrm{d})\end{array}$} \\
\hline & & Mean & SD & Actual & Planned & Actual & Planned \\
\hline 1 & 1 & $414 \cdot 3$ & $6 \cdot 3$ & 447.5 & $452 \cdot 5$ & 1.68 & 1.7 \\
\hline 2 & 2 & 419.0 & 8.8 & 318.4 & 318.4 & 1.70 & 1.7 \\
\hline 3 & 3 & 416.5 & $9 \cdot 2$ & 362.4 & $364 \cdot 5$ & 1.69 & 1.7 \\
\hline
\end{tabular}

* For details, see Tables 1 and 2.

\section{RESULTS}

\section{Diets}

All the diets were readily accepted by all the children and none of the food was refused. The actual dietary intakes at every meal were calculated from the difference in weight of the cup, before and after feeding, and are shown in Table 3 . The intakes, by weight, during each dietary period were virtually identical. Thus, there was no overlap in the energy intakes on the different diets.

\section{Weight change}

Linear regression. As a first step, changes in weight were assessed by linear regression analysis of weight $v$. time for each study period (Snedecor \& Cochran, 1980). All the children gained weight on diet 1 at 2.3 (SD 1.3) $\mathrm{g} / \mathrm{kg}$ per d, and five of the six gained weight on diet 3 , the mean for the whole group being 2.7 (SD 2.3 ) g/ kg per d (not significantly different by Wilcoxon Rank). In contrast, all the children lost weight on diet 2 at -5.4 (SD $1.3) \mathrm{g} / \mathrm{kg}$ per $\mathrm{d}$, significantly different $(P<0.01)$ from each of the other dietary periods (Fig. 1).

Asymptotic regression. Linear analysis is adequate for showing the overall trends in weight gain, but fails to detect changes in the pattern of weight gain during the course of a study week. When mean weights for each day were calculated, the trend on diet 2 was clearly non-linear, with a decrease in the rate of weight loss towards the end of the week (Fig. 2). There was also the suggestion of a non-linear trend on diet 3, but this was not as obvious. The values were fitted to the Mitscherlich (1909) growth function, a curvilinear function which tends towards an asymptote. (A Mitscherlich (1909) function is of the form $Y=\mathrm{A}-\mathrm{BR}^{X}$, where $Y$ is weight, $X$ is the day of the study period and A, B and $\mathrm{R}$ are calculated constants.) The values fitted the asymptotic function well, although we were not able to demonstrate a marked statistical improvement over the linear model. The rates of weight change calculated from the Mitscherlich (1909) regression function for diet 2 showed a marked tailing off of weight loss over the course of the study week, decreasing from -11 to $-2 \mathrm{~g} / \mathrm{kg}$ per $\mathrm{d}$. It was not possible to demonstrate such a change on diet 1 $(2 \cdot 3$ and $2.4 \mathrm{~g} / \mathrm{kg}$ per $\mathrm{d})$. There was a suggestion of a tailing off in weight gain on diet 3 (Table 4).

\section{$N$ balance}

The values for protein intake, $\mathrm{N}$ losses in urine and stool, and apparent absorption and retention of $\mathrm{N}$ are shown in Table 5. Urinary $\mathrm{N}$ was responsive to the dietary energy intake, increasing as energy intake fell, being 127,190 and $165 \mathrm{mg} \mathrm{N} / \mathrm{kg}$ per $\mathrm{d}$ in diets 1,2 and 3 


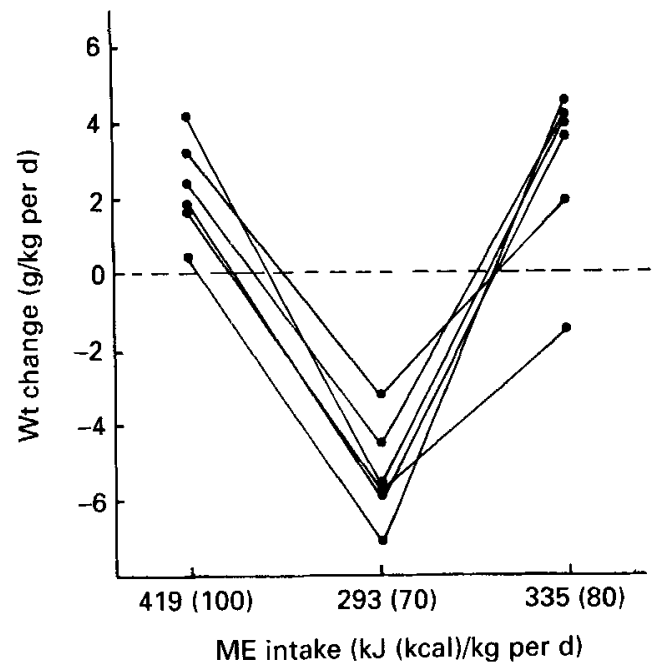

Fig. 1. Six Jamaican children were given diets that provided adequate protein and nutrients with either 419,293 or $335 \mathrm{~kJ}$ metabolizable energy (ME) $/ \mathrm{kg}$ per $\mathrm{d}$ for periods of 1 week on each successive diet. Weight was measured daily and the rate of weight change was determined by linear regression analysis over the period of $7 \mathrm{~d}$ on each diet. For details of procedures, see pp. 146-147.

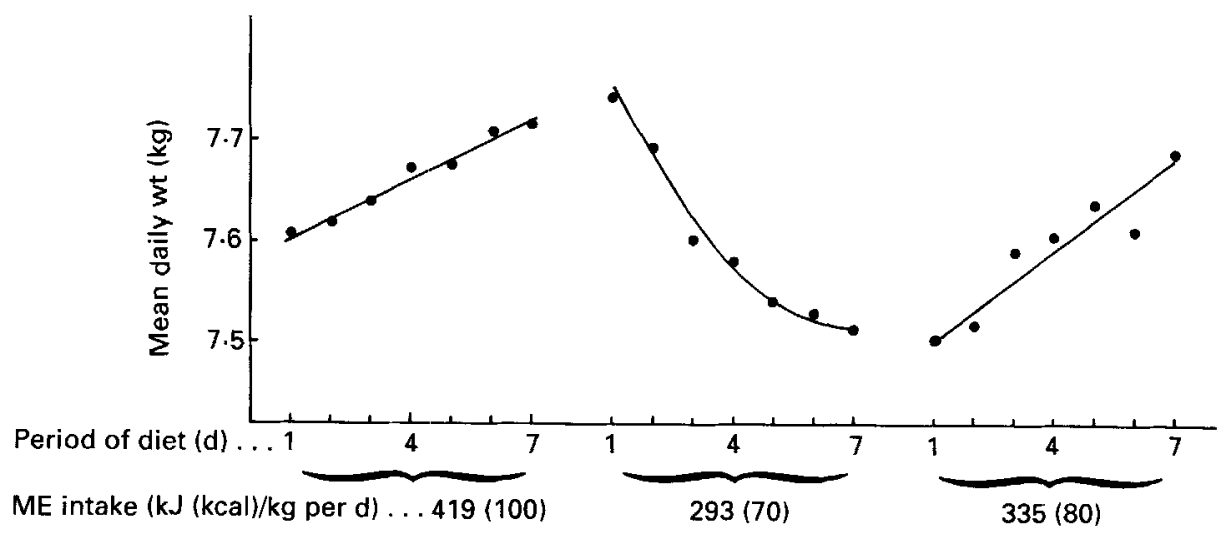

Fig. 2. Six Jamaican children were given diets that provided adequate protein and nutrients with either 419,293 or $335 \mathrm{~kJ}$ metabolizable energy (ME)/ $\mathrm{kg}$ per $\mathrm{d}$ for periods of 1 week on each successive diet. Weight was measured daily and the rate of weight change was determined by asymptotic regression analysis (Mitscherlich, 1909) on a group basis, and it was shown that on a diet providing $293 \mathrm{~kJ} \mathrm{ME} / \mathrm{kg}$ per d, weight loss tended towards an asymptote by day 7 . For details of procedures, see pp. 146-147.

respectively, approximately $0.5 \mathrm{mg} \mathrm{N} / \mathrm{kJ}$. Stools were only collected during the $24 \mathrm{~h}$ period when urine was collected. In four sample periods no stool at all was passed. If these sample periods are excluded from the analysis, no significant differences in stool losses of $\mathrm{N}$ were seen between the different weeks. However, if these periods are included and taken as showing a zero loss of $\mathrm{N}$ in stools, then the stool $\mathrm{N}$ on $\operatorname{diet} 2,10$ (SD 13) $\mathrm{mg} \mathrm{N} / \mathrm{kg}$ per d, was significantly different from diet 1,31 (SD 13) $\mathrm{mg} \mathrm{N} / \mathrm{kg}$ per $\mathrm{d}$, but not from diet 3,16 (SD 12) $\mathrm{mg} \mathrm{N} / \mathrm{kg}$ per $\mathrm{d}$. Whichever approach is used, apparent retention of $\mathrm{N}$, although decreasing with decreasing energy intake, was always positive, even on diet 2. 
Table 4. The sample standard deviation from the regression of the rates of weight change on the three diets analysed by linear regression and asymptotic regression, with the derived values for the weight change on day 1 and day 7 of each week, calculated from the Mitscherlich (1909) regression analysis of mean weight data

\begin{tabular}{|c|c|c|c|}
\hline $\begin{array}{l}\text { Week no.... } \\
\text { Diet no. }{ }^{*} \ldots\end{array}$ & $\begin{array}{l}1 \\
1\end{array}$ & $\begin{array}{l}2 \\
2\end{array}$ & $\begin{array}{l}3 \\
3\end{array}$ \\
\hline $\begin{array}{l}\text { Linear regression, } 2 \text { fitted } \mathrm{df} \\
\text { Asymptotic regression, } 3 \text { fitted } \mathrm{df} \\
\text { Day } 1(\mathrm{~g} / \mathrm{kg} \text { per } \mathrm{d}) \\
\text { Day } 7(\mathrm{~g} / \mathrm{kg} \text { per } \mathrm{d})\end{array}$ & $\begin{array}{l}0 \cdot 009 \\
0 \cdot 01 \\
2 \cdot 3 \\
2 \cdot 4\end{array}$ & $\begin{array}{r}0.025 \\
0.014 \\
-10.7 \\
-2.2\end{array}$ & $\begin{array}{l}0 \cdot 027 \\
0 \cdot 024 \\
7 \cdot 5 \\
0 \cdot 96\end{array}$ \\
\hline
\end{tabular}

* For details, see Table 2.

Table 5. Urinary and stool nitrogen, and apparent $N$ absorption and retention for the six Jamaican children ingesting 419, 293 and $335 \mathrm{~kJ} / \mathrm{kg}$ per $d$ for weeks 1,2 and 3 respectively

(Mean values and standard deviations. $\mathrm{N}$ balances were conducted at the end of each of the study weeks for each of the three diets)

\begin{tabular}{|c|c|c|c|c|c|c|}
\hline \multirow[t]{2}{*}{$\begin{array}{l}\text { Week no.... } \\
\text { Diet no. }{ }^{*} \ldots\end{array}$} & \multicolumn{2}{|c|}{$\begin{array}{l}1 \\
1\end{array}$} & \multicolumn{2}{|c|}{$\begin{array}{l}2 \\
2\end{array}$} & \multicolumn{2}{|c|}{$\begin{array}{l}3 \\
3\end{array}$} \\
\hline & Mean & SD & Mean & SD & Mean & SD \\
\hline Urine $N(\mathrm{mg} / \mathrm{kg}$ per $\mathrm{d})$ & 125 & 15 & 190 & 33 & 165 & 25 \\
\hline Stool N (mg/kg per d) & 31 & 14 & 21 & 10 & 20 & 9 \\
\hline Apparent absorption $\dagger$ (mg N/kg per d) & 239 & 16 & 243 & 3 & 247 & 10 \\
\hline Apparent retention $\dagger(\mathrm{mg} \mathrm{N} / \mathrm{kg}$ per $\mathrm{d})$ & 112 & 25 & 54 & 34 & 82 & 20 \\
\hline
\end{tabular}

* For details, see Table 2.

$\dagger$ On three occasions during week 2 and on one occasion during week 3 no stools were passed during the $24 \mathrm{~h}$ collection period. In these cases stool $\mathrm{N}$ was estimated from the mean stool $\mathrm{N}$ output of the other children for that particular study week, for the purpose of calculating absorption and retention of $\mathrm{N}$.

Our previous experience had been that all children passed stools on a daily basis, at least, and with a controlled intake of the kind used in the present study, a $24 \mathrm{~h}$ collection gave reasonably representative answers (Jackson et al. 1983). We were surprised to find that on diets 2 and 3 there was an apparent change in stool frequency. We therefore looked retrospectively to see if this was representative of a pattern. Fig. 3 shows that for the group as a whole there was a marked reduction in stool frequency on going from diet 1 to diet 2 with little further change on diet 3 . One child did not show this trend, and inclusion of his values in the analysis meant that it was not possible to demonstrate a difference that was statistically significant between the dietary groups. However, the decrease in stool frequency on diet 2 in five of the six children may well be of biological significance, and justifies the approach of assigning a zero value to stool $\mathrm{N}$ in some of the children on diets 2 and 3 when the analysis is carried out on a group basis. On diet $2 \mathrm{~N}$ balance was significantly less than on diet $1(P<0.05$, Wilcoxon Rank). 


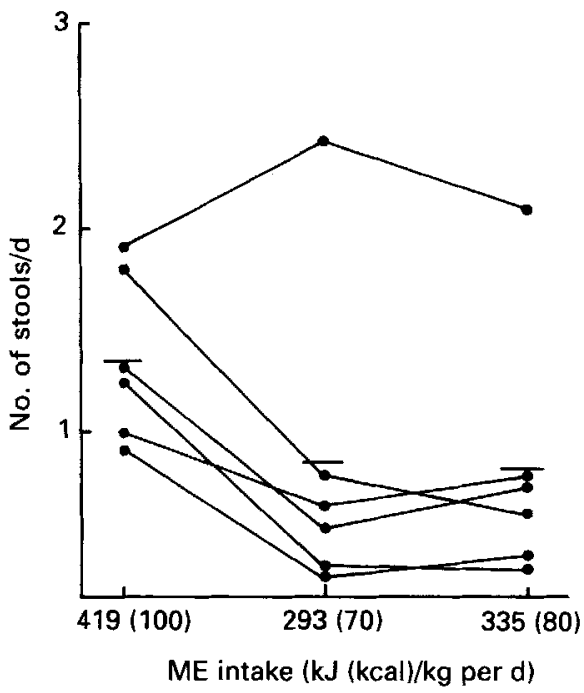

Fig. 3. The frequency of stools was determined over a period of $7 \mathrm{~d}$ for six Jamaican children consuming diets that provided adequate protein and nutrients with either 419,293 or $335 \mathrm{~kJ}$ of metabolizable energy (ME)/ $\mathrm{kg}$ per d.

\section{DISCUSSION}

The diets given provided gross energy intakes of 453,318 and $365 \mathrm{~kJ} / \mathrm{kg}$ per d, giving estimated metabolizable energy intakes of 419,293 and $335 \mathrm{~kJ} / \mathrm{kg}$ per $\mathrm{d}$ on the basis of Atwater factors and information from the milk formula manufacturer. Metabolizable energy intakes were not measured directly in the present study, but in our previous study (Jackson et al. 1983) in which urinary and faecal energy losses were measured we found a close agreement between estimated and calculated metabolizable energy intakes when using diets 3 and 1 .

\section{Weight change}

Error is inherent in the measurement of weight, due to factors such as variation in the quantity of urine and stool retained at the time of weighing. We standardized conditions as far as possible by giving the children a constant weight of food intake, weighing at the same time each day and using a sensitive electronic balance. Intra-individual variation was examined by calculating the standard deviations of weight change about the regression line for a given week. In most cases the standard deviation about the trend was in the range of $0.3-0.6 \%$ of body-weight. The highest recorded variation was $0.9 \%$ (subject 2 , sample period 2). This agrees with the findings of Khosla \& Billewicz (1964) who recorded standard deviations of $0.5 \%$ of body-weight about the weight trend in both children and adults over $30 \mathrm{~d}$ periods.

The children all responded in a remarkably similar way to the diets, gaining weight on 1 , losing weight on 2 and gaining weight again on 3 . One child, subject 1 , failed to gain weight on diet 3 . It is interesting to note that as this child was the youngest studied, he would be expected to have the highest energy requirements.

Surprisingly, the linear regression values show that overall weight gain on diet 3, following a period on diet 2 , was not significantly different from weight gain on diet 1 . Previously, no weight gain was seen when diet 3 followed a period on either 377 or $419 \mathrm{~kJ} / \mathrm{kg}$ per d (Jackson et al. 1983). The possible bases of this difference in response are worthy of consideration. 
One important possibility is that on diet 2 an adaptive mechanism was brought into play allowing for a greater efficiency of energy utilization, and that this effect persisted into the period on diet 3 . If we allow this speculation, and assuming balanced tissue deposition with an energy content of $21 \mathrm{~kJ}(5 \mathrm{kcal}) / \mathrm{g}$ (Spady et al. 1976; Jackson et al. 1977; FAO/WHO/UNU Expert Consultation, 1985) it is possible to calculate the energy available for metabolism. This cost of growth analysis reveals that the energy available for basal requirements would be 272 and $377 \mathrm{~kJ} / \mathrm{kg}$ per d on diets 3 and 1 respectively, implying that the adaptive mechanisms were responsible for an energy saving of $105 \mathrm{~kJ} / \mathrm{kg}$ per $\mathrm{d}$. As weight loss tailed off markedly during the week on diet 2 , it would mean that any adaptive change would have occurred within a few days of moving onto this diet. A saving of this magnitude could not have been accommodated simply by reducing physical activity, even if the children had remained torpid all day. There were no obvious or gross changes in the behaviour of the children on any of the diets; however, children in Guatemala were able to accommodate a $10 \%$ reduction in energy expenditure by behavioural adaptations, which were not obvious without careful measurements being taken (Torun \& Viteri, 1981).

It is possible that a large proportion of the weight change observed on diets 2 and $3 \mathrm{might}$ have been due to changes in the water or glycogen pools in the children. If this were so then $21 \mathrm{~kJ} / \mathrm{g}$ may be an overestimate of the cost of tissue deposition, which would, thus, result in an overestimation of any reduction of basal energy requirements. It is not possible for us to exclude these as possibilities; however, the finding that any weight gain occurred at all on diet 3 is in itself remarkable. Taken together with the finding of a positive $\mathrm{N}$ balance, the findings suggest that some degree of adaptation must have occurred on diet 2.

In the rat it has been shown that the accumulation of energy in the carcase over an $8 \mathrm{~d}$ period was five times greater in fasted-refed animals than in suitably matched controls, despite almost identical energy intakes (Bjorntrop et al. 1982; Bjorntrop \& Yang, 1982). Although of a greater extent, the apparent adaptive response in rats bears many similarities to the process that we have observed in children. It has been reported that in obese women weight loss could be sustained on a relatively generous intake of energy, provided that the threshold level for stimulating the adaptive response was not crossed (Wilkin et al. 1983).

\section{$N$ balance}

In an earlier study we had noted an apparent defence of $\mathrm{N}$ balance on a diet providing $1.7 \mathrm{~g}$ protein $/ \mathrm{kg}$ per $\mathrm{d}$ and $335 \mathrm{~kJ} / \mathrm{kg}$ per $\mathrm{d}$. Two children were found to have a greater $\mathrm{N}$ retention when taking 335 than $377 \mathrm{~kJ} / \mathrm{kg}$ per d (Jackson et al. 1983). We have now demonstrated that this defence of $\mathrm{N}$ retention can be maintained down to a level of 293 $\mathrm{kJ} / \mathrm{kg}$ per d. It is not possible to comment on the quality of the weight loss during the first part of the week on diet 2 , but clearly by day 7 of this week any weight loss that was being sustained was more likely to be adipose than lean tissue. The retention of $\mathrm{N}$ on diets 1 and 3 was not different, and for both was significantly greater than on diet 2. Although a dependency of $\mathrm{N}$ balance on energy intake has been well documented in the past (Inoue et al. 1973; Calloway, 1975), the extent to which the body is capable of defending $\mathrm{N}$ balance as energy intake falls has not been as widely appreciated.

It is possible to compare the findings in the present work with our earlier results (Jackson et al. 1983). On diet 1 there is no significant difference in $\mathrm{N}$ retention between the two studies, 112 (SD 25) and 81 (SD 30) $\mathrm{mg} \mathrm{N} / \mathrm{kg}$ per $\mathrm{d}$, and in both studies the range is wide. In contrast the range is much narrower on diet 3 , and there is a significant difference between the present study when diet 3 followed diet 2, 82 (SD 20) $\mathrm{mg} \mathrm{N} / \mathrm{kg}$ per d, compared with the study when diet 3 followed either diet 1 or a diet providing $377 \mathrm{~kJ} / \mathrm{kg}$ per d, 46 (SD 15) $\mathrm{mg} \mathrm{N} / \mathrm{kg}$ per $\mathrm{d}(P<0.05)$. One should be cautious about reading too much into these findings, but the evidence does demonstrate a better retention in the present study. 
This observation is in keeping with the suggestion that a period on diet 2 leads to a greater efficiency of utilization of energy and nutrients.

One important feature of the present study is that an adequate intake of all nutrients was assured, as the specific variable in which we had interest was dietary energy. Although it is useful to compare our results with those of others, this factor should be remembered. Similar studies have been carried out in preschool children treated with a mixed diet based on locally available foodstuffs. Iyengor et al. (1981) found that the faecal output of $\mathrm{N}$ was greater in children from Hyderabad given energy intakes ranging from 419 to $293 \mathrm{~kJ} / \mathrm{kg}$ per $\mathrm{d}$ with a constant protein intake of $1.75 \mathrm{~g} / \mathrm{kg}$ per $\mathrm{d}$. This might be attributed to the fact that the children were on a mixed diet, especially as it has been suggested that dietary nondigestible carbohydrate has a more obvious effect on increasing faecal $\mathrm{N}$ in the developing world (Espinoza et al. 1984). Long term studies on children in Thailand show that satisfactory growth and $\mathrm{N}$ balance might be achieved for periods up to $120 \mathrm{~d}$ on diets providing $344-453 \mathrm{~kJ} / \mathrm{kg}$ per $\mathrm{d}$ and about $1.7 \mathrm{~g}$ protein $/ \mathrm{kg}$ per d, demonstrating their adequacy (Tontisirin et al. 1984).

In the present study we have shown that $\mathbf{N}$ balance can be maintained in children on an intake of energy providing $293 \mathrm{~kJ} / \mathrm{kg}$ per d and $1.7 \mathrm{~g}$ protein $/ \mathrm{kg}$ per $\mathrm{d}$. On this intake there is an initial period of more rapid weight loss which is followed by a slowing in the rate of loss after $3-4 \mathrm{~d}$, approaching an asymptote by $7 \mathrm{~d}$. The accommodation that takes place appears to be carried forward into a later period where the energy intake is increased to 365 $\mathrm{kJ} / \mathrm{kg}$ per $\mathrm{d}$. These findings are unlikely to cause us to modify our views on the requirements for protein and energy in childhood, but they do raise important questions about possible mechanisms of adaptation to low energy and low protein intakes.

The authors are grateful to the Wellcome Trust for support in carrying out this project, which was conducted while N.K. was in receipt of a Wellcome Research Studentship.

\section{REFEREN CES}

Badaloo, A., Jackson, A. A. \& Jahoor, F. (1989). Whole body protein turnover and resting metabolic rate in homozygous sickle cell disease. Clinical Science 77, 93-97.

Bjorntorp, P., Edstrom, S., Kral, L. G., Lundholm, K., Preston, E., Walks, D. \& Yang, M.-V. (1982). Refeeding after fasting in the rat: energy substrate fluxes and replenishment of energy stores. American Journal of Clinical Nutrition 36, 450-456.

Bjorntorp, P. \& Yang, M.-V. (1982). Refeeding after fasting in the rat.American Journal of Clinical Nutrition 36, 444449.

Calloway, D. H. (1975). Nitrogen balance of men with marginal intakes of energy and protein. Journal of Nutrition 105,914923

Espinoza, J., Brunser, O., Araya, M., Egana, J. I., Pacheco, I. \& Krause, S. (1984). The effect of dietary fibre on digestibility of nutrients on a typical Chilean diet. In Protein-Energy-Requirement Studies in Developing Countries, pp. 294-305 [W. M. Rand, R. Uauy and N. S. Scrimshaw, editors]. Tokyo: United Nations University.

Food and Agriculture Organization/World Health Organization/United Nations University Expert Consultation (1985). Energy and Protein Requirements. Technical Report Series no. 724. Geneva: WHO.

Geissler, C. A. \& Aldouri, M. S. H. (1985). Racial differences in the energy cost of standardised activities. Annals of Nutrition and Metabolism 29, 40-47.

Golden, M. H. N., Golden, B. E. \& Jackson, A. A. (1981). Method of trace element balance in young children. In Trace Element Metabolism in Man and Animals, 4th ed., pp. 69-72 [J. McC. Howell, J. M. Gawthorne and C. C. White, editors]. Canberra : Australian Academy of Science.

Golden, M. H. N., Waterlow, J. C. \& Picou, D. (1977 a). Protein turnover, synthesis and breakdown before and after recovery from protein-energy malnutrition. Clinical Science and Molecular Medicine 53, 473-477.

Golden, M. H. N., Waterlow, J. C. \& Picou, D. (1977 b). The relationship between dietary intake, weight change, nitrogen balance and protein turnover in man. American Journal of Clinical Nutrition 30, 1345-1348.

Hamill, P. V. V., Drizd, T. A., Johnson, C. L., Reed, R. B., Roche, A. F. \& Moore, W. M. (1979). Physical growth: National Center for Health Statistics Percentiles. American Journal of Clinical Nutrition 32, 607-629. 
Henry, C. J. K. \& Rees, D. G. (1988). A preliminary analysis of basal metabolic rate and race. In Comparative Nutrition, pp. 149-159 [K. Blaxter and I. Macdonald, editors]. London: John Libbey.

Inoue, G., Fujita, Y.\& Niiyama, Y. (1973). Studies on the protein requirement of young men fed egg protein and rice protein with excess and maintenance energy intakes. Journal of Nutrition 103, 1673-1687.

Iyengor, A. K., Narasinga Rao, B. S. \& Reddy, V. (1981). Nitrogen balance in Indian preschool children receiving the safe level of protein at varying levels of energy. British Journal of Nutrition 46, 295-311.

Jackson, A. A., Picou, D. \& Reeds, P. J. (1977). The energy cost of repleting tissue deficits during recovery from protein-energy malnutrition. American Journal of Clinical Nutrition 30, 1514-1517.

Jackson, A. A., Golden, M. H. N., Byfield, R., Jahoor, F., Royes, J. \& Soutter, L. (1983). Whole body protein turnover and nitrogen balance in young children at intakes of protein and energy in the region of maintenance. Human Nutrition: Clinical Nutrition 37 C, 433-466.

Kerr, D. S., Stevens, M. C. G. \& Robinson, H. M. (1978). Fasting metabolism in infants 1. Effect of severe undernutrition on energy and protein utilisation. Metabolism 27, 411-435.

Khosla, T. \& Billewicz, W. Z. (1964). Measurement of change in body weight. British Journal of Nutrition 18, 227-239.

Liu, H. Y. \& Anderson, G. J. (1967). A method for the long term quantitative and fractional collection of urine. Journal of Pediatrics 70,. 276-279.

Mitscherlich, E. A. (1909). Das Gesetz des Minimums und das Gesetz des abnehmenden Bodenertrages. Landwirtschaftliche Jahrbucher (Agricultural Yearbook) 38, 537-552.

Reeds, P. J., Fuller, M. F. \& Nicholson, B. A. (1985). Metabolic basis of energy expenditure with particular reference to protein. In Substrate and Energy Metabolism, pp. 46-57 [J. S. Garrow and D. Halliday, editors]. London: John Libbey.

Shetty, P. S. (1984). Adaptive changes in basal metabolic rate and lean body mass in chronic undernutrition. Human Nutrition: Clinical Nutrition 38C, 443-451.

Snedecor, G. W. \& Cochran, W. G. (1980). Statistical Methods, 7th ed., Chapter 19. Ames, Iowa: Iowa State University Press.

Spady, D. W., Payne, P. R., Picou, D. \& Waterlow, J. C. (1976). Energy balance during recovery from malnutrition. American Journal of Clinical Nutrition 29, 1073-1078.

Tontisirin, K., Ajmanwra, N. \& Valyasevi, A. (1984). Long-term study on the adequacy of usual Thai weaning food for young children. In Protein-Energy-Requirement Studies in Developing Countries, pp. 265-285 [W. M. Rand, R. Uauy and N. S. Scrimshaw, editors]. Tokyo: United Nations University.

Torun, B. \& Viteri, F. E. (1981). Energy requirements of pre-school children and effects of varying energy intake on protein metabolism. In Protein-Energy-Requirements of Developing Countries: Evaluation of New Data, Suppl. 5, pp. 229-241 [B. Torun, V. R. Young and W. M. Rand, editors]. Tokyo: United Nations University.

Waterlow, J.C. (1984). Protein turnover with special reference to man. Quarterly Journal of Experimental Physiology 9, 409-438.

Waterlow, J. C. (1988). The variability of energy metabolism in man. In Comparative Nutrition, pp. 133-139 [K. Blaxter and I. Macdonald, editors]. London: John Libbey.

Whitehead, R. G., Paul, A. A. \& Cole, T J. (1981). A critical analysis of measured food energy intakes during infancy and early childhood in comparison with current international recommendations. Journal of Human Nutrition 35, 339-348.

Wilkin, T. J., Choquet, R. C., Schmouker, Y., Rouquette, N., Baldet, L. \& Vannereau, D. (1983). Maximum calorie (sub-threshold dieting) of the obese and its hormonal response. Acta Endocrinologica 103, $184-187$. 